


\title{
EFFECT OF MULCH AND MIXED CROPPING GRASS - LEGUME AT SALINE SOIL ON GROWTH, FORAGE YIELD AND NUTRITIONAL QUALITY OF GUINEA GRASS
}

\author{
F. Kusmiyati, Sumarsono, Karno and E. Pangestu \\ Faculty of Animal Science and Agriculture, Diponegoro University \\ Tembalang Campus, Semarang 50275 - Indonesia \\ Corresponding E-mail :fkusmiyati@yahoo.co.id \\ Received December 18, 2012; Accepted February 02, 2013
}

\begin{abstract}
ABSTRAK
Penelitian ini bertujuan untuk mengkaji pengaruh dosis mulsa dan sistem tanam rumput dan legum pada tanah salin terhadap pertumbuhan, produksi hijauan dan kualitas rumput benggala. Tanah salin pada percobaan ini diklasifikasikan dalam tanah sangat salin dengan kesuburan tanah yang rendah. Rancangan percobaan adalah rancangan acak kelompok dengan 3 kelompok. Perlakuan adalah penanaman rumput benggala : M1 = monokultur, tanpa mulsa, $\mathrm{M} 2=$ monokultur, mulsa 3 ton/ha, $\mathrm{M} 3=$ monokultur, mulsa 6 ton/ha, M4 = tumpangsari dengan legum turi, tanpa mulsa, M5 = tumpangsari dengan turi, mulsa 3 ton/ha, M6 = tumpangsari dengan turi, mulsa 6 ton/ha. Data yang diperoleh diolah dengan analisis ragam dilanjutkan dengan uji wilayah berganda Duncan. Kadar air tanah tertinggi ditemukan pada perlakuan tumpang sari rumput dan legum dengan mulsa 6 ton/ha. Pertumbuhan, produksi dan kualitas hijauan rumput benggala tertinggi pada perlakuan dengan mulsa. Aplikasi mulsa 3 ton/ha pada tanah salin sudah meningkatkan pertumbuhan, produksi dan kualitas hijauan rumput benggala. Tumpangsari rumput dan turi tidak mempengaruhi pertumbuhan, produksi dan kualitas hijauan rumput benggala pada tanah salin.
\end{abstract}

Kata kunci : mulsa, produksi, rumput benggala, tanah salin, tumpangsari

ABSTRACT

The research was conducted to evaluate the effect of mulch and mixed cropping grass - legume at saline soil on growth, forage yield and nutritional quality of guinea grass. Saline soil used in this research was classified into strongly saline soil with low soil fertility. The research was arrranged in randomized complete block design with 3 blocks. The treatments were : M1 = guinea grass monoculture, without mulch; M2 = guinea grass monoculture, 3 ton/ha mulch; M3 = guinea grass monoculture, 6 ton/ha mulch, M4 = mixed cropping grass with Sesbania grandiflora, without mulch; M5 = mixed cropping grass with Sesbania grandiflora, 3 ton/ha mulch; M6 = mixed cropping grass with Sesbania grandiflora, 6 ton/ha mulch. Data were analyzed using analysis of variance, then followed by Duncan's Multiple Range Test. The highest soil moisture content was achieved at mixed cropping grasslegume with 6 ton/ha of mulch. The effect of mulch at saline soil significantly increased plant growth, forage yield and nutritional quality of guinea grass. Application of 3 ton/ha mulch increased plant growth, forage yield and nutritional quality of guinea grass. Plant growth, forage yield and nutritional quality of guinea grass were not affected by monoculture or mixed cropping with Sesbania at saline soil.

Keywords : forage yield, guinea grass, mixed cropping,mulch, saline soil

\section{INTRODUCTION}

The most limiting factors to plant productivity are environmental stresses such as drought stress and salinity stress. Salinity stress is caused by an excess of $\mathrm{NaCl}$ at soil. Intrusion of $\mathrm{NaCl}$ from sea water to the land along coastal area of island is one reason of saline soil. The impacts of salinity stress on plants are very detrimental. Salinity stress will cause osmotic stress and ion toxicity (Zhu, 2002). Salinity reduces the plant ability to take up water and this quickly causes reduction in growth rate. If excessive amount of salt enter the plant, salt will eventually rise the toxic levels in the older transpiring leaves, causing premature senescence and reduce the 
photosintetic leaf area of the plant to a level that cannot sustain growth (Munns, 2002).

Qadir et al. (2008) suggested that crop diversification systems based on salt-tolerant plant species are likely to be the key to future agricultural and economic growth in regions where salt-affected soils exist. Salt-tolerance grasses and legumes could be grown as pure stand/monoculture or mixed stand. Among forage species, Sesbania has shown promise for biomass production on moderately saline sodic soils (Qadir et al., 2008). Sesbania is classified into legume. Kusmiyati et al. (2012) compared 5 forage grasses (P. maximum, S. sphacelata, E. mexicana, B. brizantha and C. plectostacyus) at non saline and saline soil. Based on mineral concentration, $P$. maximum showed the most tolerant plant.

Mulch is being used for its beneficial effects on crop growth and yield such as reducing soil temperature (Duppong et al., 2004), conserving soil moisture content (Athy et al., 2006; Duppong et al., 2004), reducing weed growth (Duppong et al., 2004), reducing soil erosion (Dahiya et al., 2001), increasing nitrogen and potassium of plant (Wang et al., 2008), increasing leaf area index (Fahrurozzi et al., 2005), increasing carbon (Wang et al., 2009), and reducing evaporation (Taban and Naeini, 2006).

Increasing saline soil along the north sea of Central Java can be managed by changed farm management practices. The use of mulch and mixed cropping grass - legume at that saline soil has not well documented yet. The research was conducted to evaluate the effect of mulch and mixed cropping grass - legume at saline soil on growth, forage yield and nutritional quality of guinea grass.

\section{MATERIALS AND METHODS}

This research was done at saline soil in Kaliori sub-district area, Rembang District, Central Java Province from Maret to July 2012. Before planting, soil tillage was done. The anorganic fertilizer used were $60 \mathrm{~kg} \mathrm{~N} / \mathrm{ha} /$ cutting, $150 \mathrm{~kg} \mathrm{P} \mathrm{O}_{5} / \mathrm{ha}$ and $100 \mathrm{~kg} \mathrm{~K} / \mathrm{O} / \mathrm{ha}$. Manure and rice husk ash were also applied. Fertilizer was applied after soil tillage. Plant material was pols of guinea grass (Panicum maximum). The size of plot was $4 \mathrm{~m} \times 4.5 \mathrm{~m}$. The grass row spacing was $100 \mathrm{~cm} \times 75 \mathrm{~cm}$.

Experiment design was arranged in randomized complete block design with 3 blocks.
The treatments were : M1 = guinea grass monoculture, without mulch; M2 = guinea grass monoculture, 3 ton/ha mulch; M3 = guinea grass monoculture, 6 ton/ha mulch; M4 = mixed cropping grass with Sesbania grandiflora, without mulch; M5 = mixed cropping grass with Sesbania grandiflora, 3 ton/ha mulch; . M6 = mixed cropping grass with Sesbania grandiflora, 6 ton/ha mulch.

Rice straw was used as mulch that applied at the surface of soil before planting. Sesbania grandiflora was planted between grass row. Four weeks after planting, all the grass were cut to a suitable height of $15 \mathrm{~cm}$ to uniform the plant material without recording growth and production data (first cut). The second cut of grass was 40 days after first cut.

Environment parameters observed were soil and microclimate. Soil parameters were soil texture, $\mathrm{pH}$, electrical conductivity (EC), nitrogen, phosphorous, potassium, C-organic. cation exchange capacity (CEC), sodium exchangeable (Sulaeman et al., 2005), sodium absorption ratio (SAR), and exchange sodium percentage (ESP) (Abrol et al., 1988). Microclimate including soil moisture content and air temperature were also observed. Soil moisture content measured every two weeks from first cut until second cut.

Plant parameters observed were plant height, number of leaf, number of tiller, fresh yield, dry matter (DM) yield, crude protein (CP), acid detergent fiber (ADF), and neutral detergent fiber (NDF). Plant height, number of leaf and number of tiller were measured every week after first cut until second cut. At the second cut, grass on an area of $3 \mathrm{~m}^{2}$ from the center of each plot was cut at $10 \mathrm{~cm}$ above soil and weighed to get fresh forage yield of every plot. This sample was also used for measurement of nutritional quality parameter. One hundred gram of fresh yield was dried at $105^{\circ} \mathrm{C}$ until the weigh of sample was constant to measure dry matter percentage. Dry matter yield was calculated by multiply dry matter percentage and fresh yield. Procedure of Association of Official Analytical Chemists (AOAC, 1984) was used for determination of crude protein. The $\mathrm{N}$ concentration was measured using the Kjeldahl method and the $\mathrm{CP}$ was achieved by $\mathrm{N}$ multiplied to 6.25. ADF and NDF were determined according to Van Soest et al. (1991).

The results were analyzed using analysis of variance, then followed by Duncan's Multiple 
Range Test to compare the difference between treatments according to Steel and Torrie (1980).

\section{RESULTS AND DISCUSSION}

\section{Soil Properties and Microclimate}

The soil texture was soil loam with $\mathrm{pH} 7.8$ and EC $8.7 \mathrm{dS} / \mathrm{m}$. Nitrogen $(\mathrm{N})$, phosphorous $(\mathrm{P})$ and potassium $(\mathrm{K})$ content in saline soil were $0.01 \%, 44.47 \mathrm{mg} / \mathrm{kg}$ and $3.62 \mathrm{mg} / \mathrm{kg}$, respectively. Cation exchange capacity was $12,99 \mathrm{Cmol} / \mathrm{kg}$. Sodium exchangeable was $132.31 \mathrm{Cmol} / \mathrm{kg}$. SAR and ESP were 31.5 and $78.4 \%$, respectively. Based on classification by Abrol et al. (1988), saline soil used in this research was classified into strongly saline soil (EC between $8-16 \mathrm{dS} / \mathrm{m}$ ), only tolerance crops yield satifactorily at this saline soil. Nutrient content of soil (N, P, K) was very low. Exchange sodium percentage (ESP) was very high. Excess salts in soil and high level of exchangeable sodium detrimentally affected plants both physically and chemically.

Buckman and Brady (1969) reported that soil organic matter at mineral soil was $1-5 \%$. Measurement of soil organic matter is commonly provided by total organic C. Carbon percentage of the saline soil at this experiment $(0.26 \%)$ was low. Organic carbon of saline soil at this experiment was increased to $1 \%$ by adding manure. Manure was added to each plot at dosage $200 \mathrm{~kg} / \mathrm{plot}$ or 115 ton/ha. Manure added at saline soil will improve soil physical and chemical fertility.

Soil moisture content during the experimental period are shown at Figure 1. Soil moisture content was at range $6-21 \%$. The highest soil moisture content was achieved at mixed cropping grass-legume with 6 ton/ha of mulch. Soil moisture content was low at monoculture grass without mulch and mixed cropping grasslegume without mulch. Mulch application increased moisture content of soil by reducing soil evaporation. Duppong et al. (2004) reported that higher soil moisture levels were retained under all mulches compared with non mulched treatment. Air temperature during experiment period was ranged $29-37^{\circ} \mathrm{C}$.

\section{Plant Growth}

Result of analysis of variance showed that plant height, number of leaf and number of tiller of guinea grass were significantly $(\mathrm{P}<0.05)$ affected by the treatments. Result of Duncan test showed that the effect of mulch at saline soil should be significantly increased $(\mathrm{P}<0.05)$ plant growth than without mulch. Adding 3 ton/ha or 6 ton/ha of mulch to saline soil were not significantly increased the plant growth (Table 1). Plant growth of guinea grass was not affected by monoculture or mixed cropping with Sesbania.

The plant growth of guinea grass at saline soil should be significantly higher $(\mathrm{P}<0.05)$ at mulch treatment than without mulch. Crop

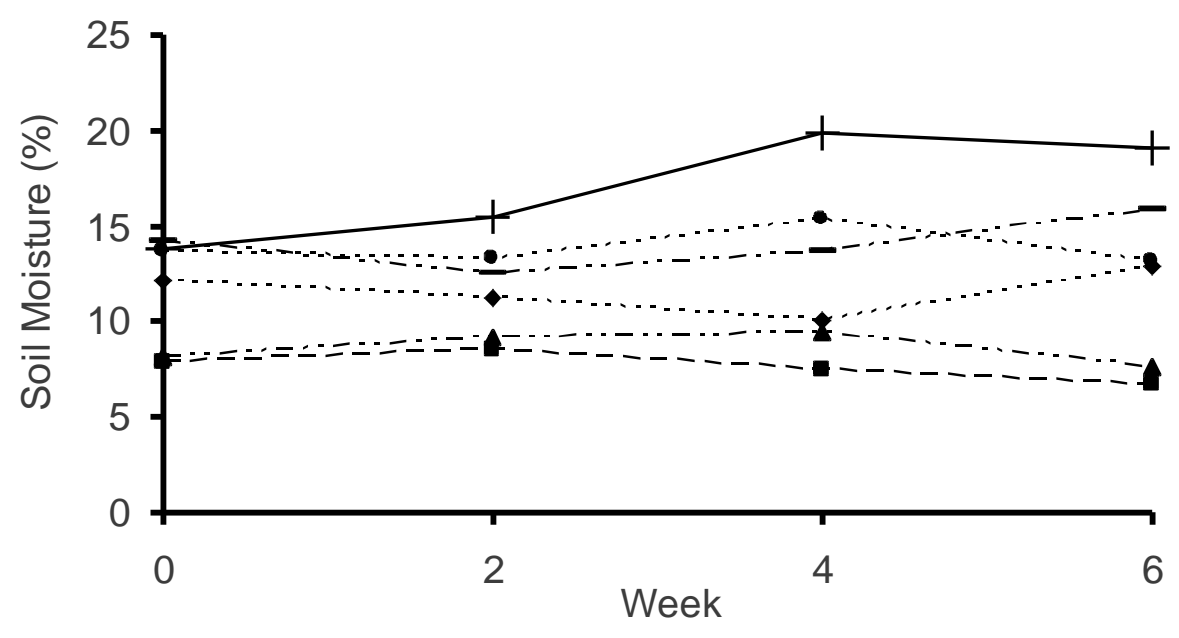

Figure 1. Soil Moisture Content during Experimental Period. M1 $(\mathbf{a})=$ guinea grass monoculture, without mulch; M2 $(\boldsymbol{\nabla})$ = guinea grass monoculture, 3 ton/ha mulch; M3 $(\boldsymbol{\nabla})=$ guinea grass monoculture, 6 ton/ha mulch; M4 $(\boldsymbol{\Delta})=$ mixed cropping grass with Sesbania grandiflora, without mulch; M5 $(\downarrow)=$ mixed cropping grass with Sesbania grandiflora, 3 ton/ha mulch; and M6 $(-)=$ mixed cropping grass with Sesbania grandiflora, 6 ton/ha mulch. Data points are mean value. 
residues left on the soil surface as mulch reduced the initial rate of evaporation, which resulted in short term in a larger average moisture content in the soil. Coppens et al. (2006) reported that leaving crop residues at the soil surface reduced water loss by $47-59 \%$ compared with the control/without residues.

Plant at saline soil faced osmotic stress. Ion $\mathrm{Na}$ and $\mathrm{Cl}$ in the soil solution decreased the availability of water to roots. Salinity reduces the ability of plant to take up water (Munns, 2002). The applied of mulch at saline soil will decreased the osmotic stress on plants. Mulch reduced the evaporation, so the moisture content in the soil can be accessed by plants. Water is very important for plants. Water is one of the essential components for plants. There are many function of water for plants. When water is available, all the process in plant will work properly. Therefore, the plant growth including plant height, number of leaf and number of tiller will increase.

Plant growth of guinea grass was not affected by monoculture or mixed cropping with Sesbania. There are several advantages of mixed cropping grass - legumes over monoculture in forage crop production systems. Legumes have ability to fix atmospheric free nitrogen by symbiotic living with Rhizobium and sustaining soil fertility. Grass can get the benefit from nitrogen fixed by legumes when they are grown together. Grass provide high dry matter yield but it produces forage with low protein. In the other hand, legume is high protein feed. At this research, plant growth of guinea grass at monoculture was not significantlly different to mixed cropping grass-legume. There were no competition of nutrients, water or light between grass and legume at this time. Grass was planted at $100 \mathrm{~cm} \times 75 \mathrm{~cm}$, while Sesbania planted between row. Therefore, each plant had enough space to grow. Plant canopy of grass and legume was not overlap yet each other.

\section{Forage Yield}

Result of analysis of variance showed that the treatment was significantly $(\mathrm{P}<0.05)$ affected fresh forage and dry matter yield of guinea grass. Application of mulch significantly increased $(\mathrm{P}<0.05)$ fresh forage and dry matter yield. Fresh forage and dry matter yield of guinea grass at the same dosage of mulch were not significanly different between monoculture and mixed cropping with legume. Fresh and dry matter yied were lower at no mulch treatment (Figure 2). The lower fresh and dry matter yield were found at without mulch treatments because of the lower moisture content of the soil. Moisture content of soil at this research increased with application of mulch (Figure 1).

Fresh forage yield at this experiment was $233-1400 \mathrm{~g} / \mathrm{m}^{2}$. Dry matter yield was $71-378$ $\mathrm{g} / \mathrm{m}^{2}$ or $0.7-3.8$ ton/ha/cutting. Fresh and dry matter yield at this experiment were higher than that reported by Mansyur et al. (2005). Fresh and dry matter yield of guinea grass understorey of banana plantation were $790 \mathrm{~g} / 5 \mathrm{~m}^{2}$ and $146.51 \mathrm{~g} / 5$ $\mathrm{m}^{2}$, respectively (Mansyur et al., 2005). Although guinea grass was planted at saline soil, forage

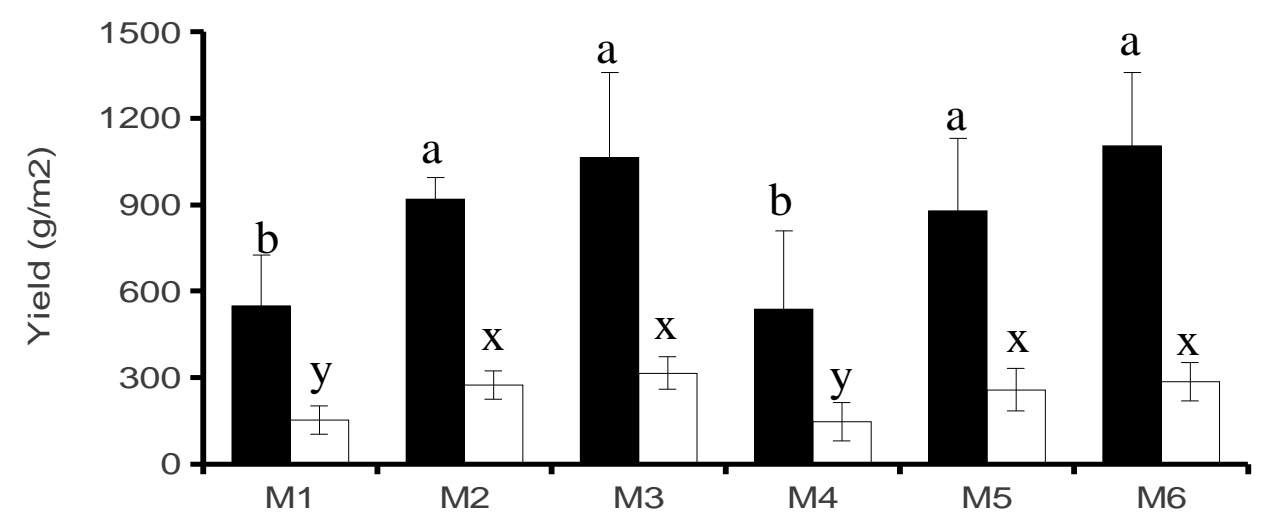

Figure 2. Fresh (- and dry matter yield ( $\square$ ) of guinea grass. M1 = guinea grass monoculture, without mulch, M2 = guinea grass monoculture, 3 ton/ha mulch, M3 = guinea grass monoculture, 6 ton/ha mulch, M4 = mixed cropping grass with Sesbania grandiflora, without mulch, M5 = mixed cropping grass with Sesbania grandiflora, M6 = mixed cropping grass with Sesbania grandiflora, 6 ton/ha mulch. Error bars represent standard deviation of the mean. 
Table 1. Plant Height, Number of Leaf and Number of Tiller of Guinea Grass at Different Treatment in Saline Soil

\begin{tabular}{lccc}
\hline \multicolumn{1}{c}{ Treatments } & Plant Height $(\mathrm{cm})$ & Number of Leaf & Number of Tiller \\
\hline Grass monoculture, without mulch & $119.2 \pm 13.13^{\mathrm{ab}}$ & $101.3 \pm 20.76^{\mathrm{b}}$ & $26.0 \pm 4.07^{\mathrm{b}}$ \\
Grass monoculture, 3 ton/ha mulch & $139.2 \pm 10.41^{\mathrm{a}}$ & $137.5 \pm 25.96^{\mathrm{a}}$ & $35.4 \pm 8.54^{\mathrm{ab}}$ \\
Grass monoculture, 6 ton/ha mulch & $139.6 \pm 12.48^{\mathrm{a}}$ & $133.9 \pm 37.06^{\mathrm{a}}$ & $41.9 \pm 19.09^{\mathrm{a}}$ \\
Grass + Sesbania, without mulch & $111.3 \pm 19.54^{\mathrm{b}}$ & $99.7 \pm 25.76^{\mathrm{b}}$ & $26.1 \pm 8.51^{\mathrm{b}}$ \\
Grass + Sesbania, 3 ton/ha mulch & $139.1 \pm 18.72^{\mathrm{a}}$ & $120.9 \pm 26.99^{\mathrm{ab}}$ & $33.8 \pm 7.63^{\mathrm{ab}}$ \\
Grass + Sesbania, 6 ton/ha mulch & $139.7 \pm 19.24^{\mathrm{a}}$ & $134.1 \pm 31.98^{\mathrm{a}}$ & $38.9 \pm 12.32^{\mathrm{a}}$ \\
\hline
\end{tabular}

Number with different letter at the same column was significantly difference $(\mathrm{P}<0.05)$

Table 2. Crude Protein (CP), Acid Detergent Fibre (ADF) and Neutral Detergent Fibre (NDF) of Guinea Grass at at Different Treatment in Saline Soil

\begin{tabular}{llll}
\hline \multicolumn{1}{c}{ Treatments } & \multicolumn{1}{c}{ CP $(\%)$} & ADF $(\%)$ & NDF $(\%)$ \\
\hline Grass monoculture, without mulch & $6.52 \pm 0.31^{\mathrm{c}}$ & $38.55 \pm 1.21^{\mathrm{a}}$ & $65.67 \pm 2.67^{\mathrm{a}}$ \\
Grass monoculture, 3 ton/ha mulch & $7.94 \pm 0.81^{\mathrm{ab}}$ & $34.64 \pm 4.36^{\mathrm{abc}}$ & $65.18 \pm 0.66^{\mathrm{a}}$ \\
Grass monoculture, 6 ton/ha mulch & $8.77 \pm 0.89^{\mathrm{a}}$ & $34.03 \pm 2.38^{\mathrm{bc}}$ & $58.38 \pm 3.92^{\mathrm{bc}}$ \\
Grass + Sesbania, without mulch & $7.16 \pm 1.16^{\mathrm{bc}}$ & $37.93 \pm 3.01^{\mathrm{ab}}$ & $65.91 \pm 1.11^{\mathrm{a}}$ \\
Grass + Sesbania, 3 ton/ha mulch & $7.93 \pm 0.12^{\mathrm{ab}}$ & $35.25 \pm 6.24^{\mathrm{abc}}$ & $62.76 \pm 2.30^{\mathrm{ab}}$ \\
Grass + Sesbania, 6 ton/ha mulch & $8.29 \pm 0.47^{\mathrm{ab}}$ & $32.10 \pm 1.74^{\mathrm{c}}$ & $56.70 \pm 5.02^{\mathrm{c}}$ \\
\hline
\end{tabular}

Number with different letter at the same column was significantly difference $(\mathrm{P}<0.05)$.

yield was higher than that was planted understorey of banana plantation. Type of photosyntesis pathway of grass is $\mathrm{C} 4$ plant. C4 plants are named for the 4-carbon molecule present in the first product of carbon fixation in the small subset of plants. Grass as C4 plant has photosynthesis rate faster under high light intensity and has better water use efficiency than C3 plants. Application of mulch increased soil moisture content. Adding manure as soil amendments at saline soil has many advantage such as increasing soil fertility and water holding capacity.

\section{Nutritional Quality}

Treatments significantly $(\mathrm{P}<0.05)$ affected $\mathrm{CP}, \mathrm{ADF}$ and NDF of guinea grass. Application of mulch significantly increased nutritional quality of guinea grass at saline soil (Table 2). Nutritional quality of guinea grass in term of high crude protein with low ADF and NDF was at treatment of 6 ton/ha mulch.

Forage grass quality is affected by many factors such as the species, cutting interval, phase of plant development, soil fertility, fertilizer, disease and climatic conditions. It is usually found that the most important factor affecting protein content in herbage dry matter is phase of plant development. Forage quality will decrease, in term of decreasing crude protein and increasing levels of cell wall constituents, with advancing maturity. At reproductive stage, the quality of grass will decrease. Phase of plant development is also related to cutting interval. Lengthening 
cutting interval will cause advancing plant maturity. Okwari and Magani (2010) reported that cutting guinea grass at 6 weeks of age significantly yielded a higher $\mathrm{CP}$ value, lower amount of ADF and NDF than cutting at 9 weeks. Forage quality decreased with the maturation of grass.

Guinea grass at this experiment was cut at six weeks but the plant maturity was different among treatment. Some of plant have already at reproductive stage or flowering. The number of guinea grass at flowering stage at no-mulch, 3 ton/ha mulch and 6 ton/ha mulch were 72.2$77.8 \%, 45.8-59.7 \%$ and $43.1-45.8 \%$ respectively. Percentage of plant flowering at no-mulch treatment was higher than 3 ton/ha mulch or 6 ton/ha mulch. Plant growth at saline soil without mulch faced more saline stress than with mulch. Soil moisture content at soil without mulch was lower than at mulch application (Figure 1). Lower soil moisture content and saline stress at plant without mulch alters the time of flowering and hence maturity. Plant under stress will be at reproductive stage early. Forage quality decreased while plant at reproductive stage.

Forage quality at grass monoculture and mixed cropping grass-legume was not significantly difference. The forage quality of guinea grass was not affected by presence of legume. Height of Sesbania was $50 \mathrm{~cm}-100 \mathrm{~cm}$ when grass was cut. Canopy of legume was not yet covered grass.

\section{CONCLUSION}

Saline soil used in this research was classified into strongly saline soil with low soil fertility. The highest soil moisture content was achieved at mixed cropping grass-legume with 6 ton/ha of mulch. The effect of mulch at saline soil increased plant growth, forage yield and nutritional quality of guinea grass. Aplication of 3 ton/ha mulch had already increased plant growth, forage yield and nutritional quality of guinea grass. Plant growth, forage yield and nutritional quality of guinea grass were not affected by monoculture or mixed cropping with Sesbania at saline soil.

\section{REFERENCES}

Abrol, I.P., J.S.V. Yadav and F.I. Massaud. 1988. Salt-Affected Soil and Their Management. AO, Rome
Association of Official Analytical Chemists (AOAC). 1984. Official Methods of Analysis. AOAC Inc., Virginia.

Athy, E.R., C. H. Keiffer and M.H. Stevens. 2006. Effects of mulch on seedlings and soil on closed landfill. Restoration Ecol. 14:233241.

Buckman, H.O., and N.C. Brady. 1969. The Nature and Properties of Soil. The Macmillan Company, New York.

Coppens, F., P. Garnier, S.De Gayze, R. Merclex, and S. Recous. 2006. Soil moisture, carbon and nitrogen dynamics following incorporation and surface application of labeled crop residues in soil column. Europ. J. Soil Sci. 57: 894-905.

Dahiya, R., R.S. Malik and B.S. Jhorar. 2001. Organic mulch decomposition kinetics in semiarid environment at bare and crop field conditions. Arid Land Res. Manag. 15:49-60.

Duppong, L.M., K. Delate, M. Liebman, R. Horton, F. Romero, G. Kraus, J. Petrich and P.K. Chowdbury. 2004. The effect of natural mulches on crop performance, weed suppression and biochemical constituents of catnip and St. John'Wort. Crop Sci. 44:861869.

Fahrurozzi, B. Hermawan and Latifah. 2005. Pertumbuhan dan hasil kedelai pada berbagai dosis mulsa alang-alang dan pengolahan tanah. J. Akta Agrosia 2:21-24.

Kusmiyati, F., Sumarsono, Karno and E. Pangestu. 2012. Mineral concentration of forage grasses at different salinity levels of soil. Proceedings, The $2^{\text {nd }}$ International Seminar on Animal Industry. Jakarta, 5-6 July, 2012. P. 171-177.

Mansyur, N. P., Indrani, I. Susilowati and T. Dhalika. 2005. Pertumbuhan dan produktivitas tanaman pakan dibawah naungan perkebunan pisang. J. Ilmu. Tanah 5:22-27.

Munns, R. 2002. Comparative physiology of salt and water stress. Plant, Cell Environt. 25:239-250.

Okwari, A. I. and Magani. 2010. Effect of nitrogen sources and harvesting on four (4) grass species in southern guinea savanna of Nigeria. Res. J. Anim. Vet. Sci. 5:23-30.

Qadir, M., A. Tubeileh, J. Akhtar, A. Larbi, P.S. Minhas and M.A. Khan. 2008. Productivity enhancement of salt-affected environments through crop diversification. Land Degrad. Develop. 19 : 429 - 453. 
Sulaeman, Suparto and Eviati. 2005. Petunjuk Teknis Analisa Kimia Tanah, Tanaman, Air dan Pupuk. Balai Penelitian Tanah, Badan Penelitian dan Pengembangan Pertanian, Departemen Pertanian.

Steel, R.G.D. and I.H. Torrie. 1980. Principles and Procedures of Statistics : A Biometrical Approach. McGraw-Hill, Inc., New York.

Taban, M. and S.A.R. M. Naeini. 2006. Effect of aquasorb and organic compost amendments on soil water retention and evaporation with different evaporation potentials and soil textures. Communication on Soil Sci. Plant Anal. 37:2031-2055.

Van Soest, P.J., J.B. Robertson and B.A. Lewis.
1991. Methods for dietary fiber, NDF and nonstructural polysaccharides in relation to animal nutrition. J. Dairy Sci. 74:3583-3597.

Wang, K.H., R. McSorley, R.N. Galleher, and N. Kokalis-Burelle. 2008. Cover crops and organic mulches for nematode, weed and plant health management. Nematology 10:231- 242.

Wang, Q., W. Klassen, Y. Li and M. Codallo. 2009. Cover crops and organic mulch to improve tomato yields and soil fertility. Agron. J. 101:345-351.

Zhu, J.K. 2002. Salt and drought sress signal transduction in plants. Annu. Rev. Plant Biol. 53:244-273. 